\title{
Building Democracy in Post-Conflict Aceh: Dynamics and Challenges
}

\author{
Mohammad Hasan Ansori \\ Department of Sociology, Faculty of Social and Political \\ Sciences \\ State Islamic University of Syarif Hidayatullah \\ Jakarta, Indonesia \\ mansori_uhm@yahoo.com \\ Rostineu \\ Department of Korea, Faculty of Humanities, \\ University of Indonesia
}

\begin{abstract}
The Aceh conflict was settled through Helsinki Peace Agreement in August 2005. The implementation of a local election, which was the very first step of democratization, right after the agreement is considered as a strategic instrument for establishing a sustainable peace in the region. However, postconflict election process can also create an entry to the emergence of new conflicts and violence. Theoretically speaking, multiple factors are frequently related to the study of postconflict democracy, covering institutional infrastructure and potential violence/conflict. The questions are 1 . how does the post-conflict election in Aceh help build democracy?; and 2. to what extent is the institutional and social preparedness in the implementation of the post-conflict election in Aceh?. Empirically, the data mainly indicate that diverse issues are closely entangled with the implementation of post-conflict election in Aceh, including governance, such as accountability, transparency, law enforcement and money politics, institutional infrastructure, capacity and integrity of election committee, including the unfairness and partiality of KIP, Panwas, PPK, $P P S, K P P S$ and potential violence and intimidation. The data are primarily derived from interviews with diverse relevant stakeholders and secondary sources, including academic publications, governmental and public reports and documents and news papers.
\end{abstract}

Keywords: post-conflict, election, democracy, peace-building

\section{INTRODUCTION}

Conflict analysts regard Indonesia, Thailand, The Philippines, and Myanmar as countries of a long history of conflicts and violence in Southeast Asia. In particular, having more than 230 million of people and more than 300 ethnical groups puts Indonesia as one of the most heterogeneous countries in the world. This heterogeneity is then reflected in a current national model of Indonesia that is often perceived as a product of negation of various interests, both ethnicity, and religion. However, various forms of large-scale violent conflicts emerged drastically in the archipelagic country in the fall of the New Order in late 1990's. Conflicts took place consecutively in Central Kalimantan, Aceh, Papua, East Timor, Maluku and Central Sulawesi, starting in December 1996. All the conflicts experienced de-escalation, if not significantly settled, at the end of 2002, except for the Aceh conflict that was settled through Helsinki Peace Agreement in August 2005.

In Indonesia, electoral violence is more dominant in postconflict areas rather than in non-post conflict ones, except for Papua, in which conflict is still ongoing. This is particularly shown by the following National Violence Monitoring System (NVMS) data on incidents and impacts of electoral violence in Indonesia between 2005 and 2013:

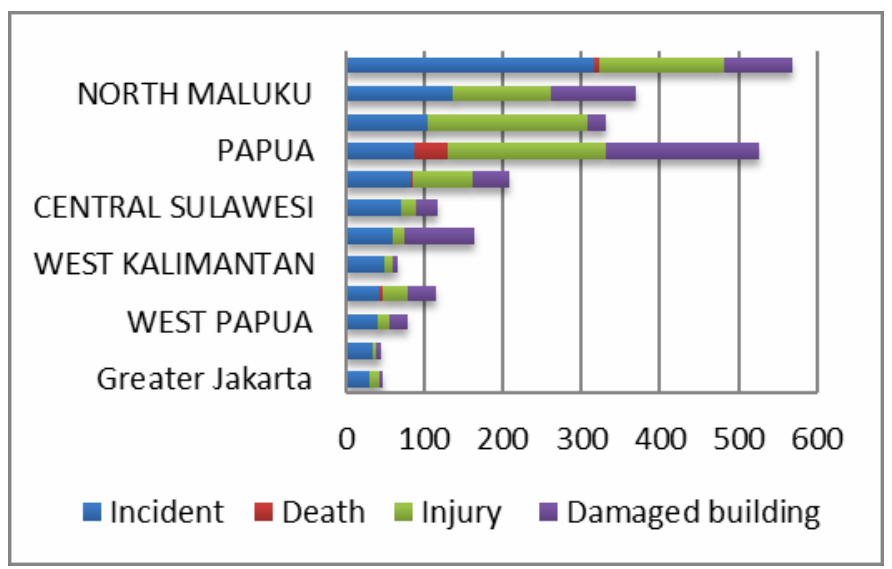

Primarily based on the data, the study takes Aceh, in which post-conflict duration in the province has reached approximately one decade, as a case study. In this context, Scwartz (1991) emphasizes that one decade is a required period to see and evaluate how change has taken place after conflicts. The questions become how post-conflict in Aceh is implemented, what are the challenges that the implementation of the post-conflict election has to face, and finally, to what extent the challenges are managed by the election committee.

The data are primarily drawn from open-ended interviews with the former members of Free Aceh Movement and the non-members. In addition to the primary sources, I used many secondary sources, including academic publications, public records, governmental documents and local and national newspapers and magazines. 


\section{POST-CONFLICT ELECTION: BETWEEN DEMOCRATIZATION AND PEACE-BUILDING}

One of the forms of conflict settlement is the execution of post-conflict election. In general, elections and democracy are regarded as one of the conflict management forms on the assumption that the benefit of this democratic competition will become a strategic instrument to manage tension and conflicts in the post-conflict society. With various reasons, postconflict elections are widely regarded as an integral part of the main process and method for peaceful end to violence/war and nation-state building. In other words, post-conflict elections also become a validation for peace-building (peacesettlement) and simultaneously become the foundation of the democratization process.

Historically, democratic intervention for both of conflict settlement and peace-building started to become stronger at the end of the Cold War and fall of Soviet Union in the early 1990s that brought about a huge impact on the victory of liberal democratic ideology and spread the wind of democratization across the world. Besides that, contextually, the end of the Cold War was then followed by an eruption of various wars and conflicts. Jarstad and Sisk (2008) even emphasized that no civil wars of the post-Cold War that were primarily settled by peace agreements had followed regional partition process (regional proliferation). It must be admitted that new states that emerged after the Cold War were not products of peace agreement negotiation. The establishment of Timor Leste, for instance, is a negotiation result between Indonesia and Portugal, instead of peace agreement result between Indonesia and Fretilin.

Contextually speaking, the term of post-conflict election is a creative innovation taken by the second generation of the peace keeping operations and then expands after the halt of the Cold War. Jarstad and Sisk emphasize that since 1990's democracy has been an integral part of international peacebuilding missions during the widespread eruption of civil wars. Namibia and El Salvador are the first states that applied the method. Besides those two states, the states that have applied post-conflict elections were Afghanistan, Kosovo, Nepal, Democratic Republic of the Congo, Irak, etc. Even Kuhne (2010) further added between 2010 and early 2011 there were more than ten post-conflict general elections conducted in various countries. In the Indonesian context, Aceh is the post-conflict region in which the execution of post-conflict general election was an integral part of the contents of the Helsinki Peace Agreement.

The core behind the execution of the post-conflict elections is two processes that are different but mutually linked (interacting twin processes), namely democratization through general elections and peace-building. Democratization refers to the open process of political space, including improvements in contestation, participation and human rights. Democracy is considered a system in which different interests are managed through continuous negotiation and accommodated through legitimate agencies. Even though various conflicts are sometimes fully settled, democracy is assumed to be able to settle them peacefully. At this level, democracy and peace support one another. Democracy can be consolidated when peaceful conflict-managing ways are acceptable. Similarly, sustainable peace requires good governance, in which various interests, complaints, and disappointment are accommodated through negotiation and compromise.

A general assumption emphasizes that democracy implies peace and vice versa (mutually beneficial processes). However, in reality, there are many paradoxes/ contradictions or dilemma in the implementation process in the field. Democracy as a political system is identical to peaceful management of conflicts, both conflicts in a country or between countries. The post-conflict democracy path is often steep and accompanied by various conflicts and violence. In a simple way, post-conflict election process can contribute to the promotion of sustainable peace, but it can create an entry to the emergence of conflicts and violence and generate new post-conflict tensions. The condition is much shaped by the competitive situation that contains dichotomy of win and loses. Furthermore, this instability may harm the sustainable peace promoting process.

\section{DYNAMIC AND CHALLENGES OF BUILDING DEMOCRACY IN POST-CONFLICT ACEH}

Post-conflict elections in Aceh are regarded as a success. Especially before the international community, and if compared with other post-conflict elections in the world, such as Afghanistan, Kosovo, Nepal, Democratic Republic of the Congo, Irak, etc. The election must be admitted as a particular accomplishment. Besides that, regarding formal-procedural dimension, it is regarded as being suitable to the prevailing rules, and therefore, on this level, it is relatively democratic. ${ }^{1}$ Irwandi Yusuf, the former Aceh Governor that is just currently re-elected as the governor of Aceh in February 2017, made an interesting assessment on the implementation of the election in Aceh by comparing it with the ones in non-conflict areas $^{2}$.

Building democracy in post-conflict Aceh started in 2006 through the implementation of the first election after the 2006 Helsinki Peace Agreement. The election was regarded as the best and eventually placed Irwandi Yusuf and Muhammad

\footnotetext{
${ }^{1}$ Interview with one of peace activists in Aceh, Banda Aceh, 23 June 2014.

2 Interviews with Sabang Panwaslu commissionaire, Sabang, 30 October 2014, with one of the senior journalists, Banda Aceh, 20 June 2014. And with Irwandi Yusuf, Banda Aceh, 24 June 2014.
} 
Nazar in the gubernatorial and vice-gubernatorial positions. Besides that, the 2006 election was considered to have created a particular history by staging pairs of gubernatorial and vice gubernatorial candidates from the independent pathway, namely Irwandi Yusuf and Muhammad Nazar. It is deemed historical in the macro context of the local election in Indonesia since the independent pathway was the first initiative taken in the Aceh election. The 2006 election ran relatively in a safe and stable manner, ${ }^{3}$ If compared to 2012 one. Even, the 2012 one was regarded as intense because since the beginning there were internal conflicts in the Aceh Party (PA). ${ }^{4}$

Some challenges and obstacles were associated with the first post-conflict lection. The first one was related to infrastructure readiness. When the 2004 Tsunami hit, many buildings were damage, including election organizing offices. The second one refers to population data for producing the DPT (List of Permanent Voters). When Tsunami hit Aceh, many Acehnese left their houses. The last one relates to the very tight readiness of election regulations. ${ }^{5}$

However, it is also critically emphasized that, at a certain level, the election was considered less democratic because of some "non-democratic" factors or actions. One of the main highlighted issues was the partiality of election organizers to certain candidates or parties. ${ }^{6}$ The selection process and election organizers' partiality issues had become a particular spotlight and common concern among activists and supporters of democracy development in Aceh. The partiality of election organizers originated from the main problem of the screening and selection processes by DPRA. Often in these processes, there were certain parties who intervened so that the people in the organizers' structure would take action and decision to fight for their interests. ${ }^{7}$ Critical attention to the organizers is given to their low capacity and characters, especially too much dishonesty done by election elements such as KIP, PPS, PPK, Panwaslu, dsb. ${ }^{8}$

Another critical note which drew the attention of many parties was widespread intimidation both verbal and physical, and which can be said to be visible in all parts of Aceh region,

\footnotetext{
${ }^{3}$ Interview with a former Aceh KIP Chief, Banda Aceh, 20 June 2014; and with commissionaire of Sabang Panwaslu Sabang, Sabang, 30 October 2014.

${ }^{4}$ Interview with Governor's Expert Assistant for Political Affairs, Banda Aceh, 31 October 2014.

${ }^{5}$ Interview with Governor's Expert Assistant for Political Affairs, Banda Aceh, 31 October 2014.

${ }^{6}$ Interview with former GAM negotiator, Banda Aceh, 23 June 2014.

${ }^{7}$ Interview with one of the peace activists in Aceh, Banda Aceh, 23 June 2014.

${ }^{8}$ Interview with one of the former BRA-Aceh chairs, Banda Aceh, 20 June 2014.
}

both in the areas that used to be GAM basis or non GAM basis. Even Sabang Island was included even though during the conflict this island was relatively peaceful due to relatively heterogeneous composition of the population. But in the 2012 election, intimidation was a common scene there. ${ }^{9}$ In general, the intimidation is aimed to influence, and at a certain level, tends to force voters to vote for a particular party or candidate. ${ }^{10}$ As it is expressed by one of the informants, "there was fear. We just had this Pemilukada for the first time. So this is an issue of people's feeling. For instance, if in this area A did not win, that would have an impact. But it cannot be proved. This becomes traumatic feeling". ${ }^{11}$

Intimidation happened both in 2006 and 2012 elections. However, the 2012 one was considered as the peak of a huge number of intimidations. Especially, verbal intimidations were more dominant, such as "If you don't vote for this party, we will always be colonized,"12 “It's obvious, if you don't vote for it, we will be in trouble again, Aceh will be in chaos, no more," 13 And there are still many other verbal-intimidating expressions. Many verbal threats make use of the people's traumatic condition to the conflicts to pressure or force people to vote for a particular party, either directly or via SMS. A message through SMS says: "We want you not to vote for the candidate you support. You must choose our candidate if you want to be safe."14

In general, many intimidating efforts were directed against Aceh Party (PA) and especially occurred massively in the 2012 election. ${ }^{15}$ Intimidating actors were mostly related to PA sympathizers. Interestingly, PA did not deny that many intimidating behaviors were conducted by its sympathizers. However, we cannot expect a confirmation from PA that it was a structural instruction. One of the PA spokespeople, for instance, emphasized that such intimidation was a normal thing, especially in the post-conflict region. ${ }^{16}$ Massive intimidations conducted by PA withdrew a particular attention from one of the founders/ former secretary of GAM, Husaini

\footnotetext{
${ }^{9}$ Interview with Sabang Panwaslu commissionaire, Sabang, 30 October 2014.

${ }^{10}$ Interviews with Irwandi Yusuf, Banda Aceh, 24 June 2014 and with one of the local journalists, Banda Aceh, 25 June 2014.

${ }^{11}$ Interview with one of the Aceh Panwaslu expert assistant, Banda Aceh, 21 June 2014.

${ }^{12}$ Interview with a Gayo resident, Banda Aceh, 22 June 2014.

${ }^{13}$ Interview with a local Bireuen NGO activist, Bireuen, 26 June 2014.

${ }^{14}$ Interview with Sabang Panwaslu commissionaire, Sabang, 30 October 2014.

${ }^{15}$ Interview with one local journalist, Banda Aceh, 25 June 2014.

${ }^{16}$ Interview with one of former GAM spokespersons, Banda Aceh, 25 June 2014.
} 
M. Hasan, stating that intimidation was a form of PA elites' behaviors that tended to think about their interest and sacrifice the people.

In general, Intimidation physically takes the form of violence and terror targeting certain groups. Particularly in 2012, it is predicted that many cases of violence accompanied the implementation of the election. ${ }^{17}$ Interestingly, cases of violence were higher in the 2012 election, around 112 cases, than in 2006 one. In 2006, there was not much violence, and often terrors occurred because at that time PA was not fractured and still solid. ${ }^{18}$ More that, Yusni Saby, former BRAAceh (Aceh Peace Reintegration Agency) Chairperson emphasized that”... here and there were violence and conflicts, but they did not end up riots. There was still aroma of conflicts during the election." 19 At this level, he sees the emergence of violence in the election process in Aceh was more a nuance of the previous conflicts that do not fully disappear.

However, in the eye of the international community, some violent incidents that claimed lives in the post-conflict election processes in Aceh are considered as being normal and tolerable. Even at a certain level, by considering the long duration of the conflicts in Aceh, such violence is deemed to be normal and, therefore, with international standard and comparison, the implementation of election in post-conflict Aceh should be deemed as a big success. ${ }^{20}$

\section{CONCLUSION}

The post-conflict elections in Aceh are intended as a form of validation for peace-settlement as well as a foundation for the democratization process in the region. The implementation of two elections in Aceh (2006 and 2012) is regarded as nonfully successful despite various unique challenges and problems in the region. In this case, being non-fully successful means that the implementation of the election in Aceh has reached a degree of promoting a sustainable peace and democracy development. The research findings have confirmed that the post-conflict election has helped develop local democracy and promote sustainable peace in Aceh.

In addition, the research finding is definitely in line with SNPK data concerning violent incidents in the elections

\footnotetext{
${ }^{17}$ Interview with one of the former BRA-Aceh chairpersons, Banda Aceh, 20 June 2014.

${ }^{18}$ Interviews with one of the senior journalists, Banda Aceh, 20 June 2014 and with one of the Bireuen NGO figures, Bireuen, 26 June 2014.

${ }^{19}$ Interview with one of the former BRA-Aceh chairpersons, Banda Aceh, 20 June 2014.

${ }^{20}$ Interview with former GAM negotiator, Banda Aceh, 23 June 2014.
}

(2005-2013). Violence and intimidations in Aceh tend to increase and spread evenly, instead of decreasing, in the 2012 election. Based on the technical-procedural dimension, the implementation in Aceh runs smoothly according to the general standard of the election. However, many criticisms are also referred to the problem of neutrality, which is believed to be more caused by the selection of Aceh KIP members by DPRA. In addition, there are still technical-procedural problems of the election in Aceh, especially related to votecounting fraud. Finally, the development of the substantive democracy in Aceh is seen as being fully achieved, such as freedom of expressions, protection of the minority, equity of social and economic development, respect to different values, views, and opinions, etc.

\section{References}

[1] M. Ansori, From insurgency to bureaucracy: Free Aceh Movement, Aceh Party and the new face of conflict. In Stability: International Journal of Security and Development, vol. 1, no. 1, p. 31-44, 2012.

[2] H. Awaluddin, Peace in Aceh: Notes on the peace process between the Republic of Indonesia and the Aceh Freedom Movement (GAM) in Helsinki. Jakarta: CSIS, 2009.

[3] J. Bertrand, Nationalism and ethnic conflict in Indonesia. Cambridge: Cambridge University Press, 2003.

[4] J. Bertrand, Ethnic conflicts in Indonesia: National models, critical junctures, and the timing of violence. In Journal of East Asian Studies, vol. 8, p. 425-449, 2008.

[5] A.K. Jarstad, Dilemma of war to democracy transitions: Theories and concepts. In A. K. Jarstad \& T. D. Sisk (ed.). From war to democracy: Dilemmas of peace-building. New York: Cambridge University Press, p. 15-36, 2008.

[6] A.K. Jarstad \& T. D. Sisk, Introduction. In A. K. Jarstad \& T. D. Sisk (ed.). From war to democracy: Dilemmas of peace-building. New York: Cambridge University Press, p. 1-15, 2008.

[7] D. Kingsbury, Peace in Aceh: A personal account of the Helsinki peace process. Singapore: Equinox Publishing, 2006.

[8] S. Korth, Highlights of the 2010 dialogue series. In The role of elections in peace processes: when and how the advance stability or exacerbate conflicts. Report is published by United Nations System Staff College (UNSSC), Turin, Italy, p. 9-18, 2008.

[9] W. Kuhne, The role of elections in emerging democracies and post-conflict countries: Key issues, lessons learnt and dilemmas. In International Policy Analysis, Friedrich Ebert Stiftung, 2010.

[10] T. Lyons, Post-conflict elections: War termination, democratization and demilitarizing politics. Working paper, no. 20, Institute for Conflict Analysis and Resolution, George Mason University, 2002.

[11] M. Malley, Political centralization and social conflict in Indonesia. In S. A. Giannakos (ed.). Ethnic conflict: Religion, identity and politics. Ohio: Ohio University Press, p. 170-187, 2002.

[12] L. Mancini, Horizontal inequality and communal violence: Evidence from Indonesian districts. In F. Stewart (ed.). 
Horizontal inequalities and conflict: Understanding group violence in multiethnic societies. New York: Palgrave Macmillan, p. 106-135, 2008.

[13] F. Oliva, Learning to lose: accepting electoral outcomes. In The role of elections in peace processes: When and how the advance stability or exacerbate conflicts. Report was published by United Nations System Staff College (UNSSC), Turin, Italy, p. 19-34, 2011.

[14] H. Przeworski \& H. Teune, The logic of comparative social inquiry. New York: Wiley-Interscience, 1970.

[15] B. Reilly, Post-war election: Uncertain turning points of transition. In A. K. Jarstad \& T. D. Sisk (ed.). From war to democracy: Dilemmas of peace-building. New York: Cambridge University Press, p. 157-181, 2008.

[16] M.L. Ross, Resources and rebellion in Aceh, Indonesia. In P. Collier \& N. Sambanis (ed.). Understanding civil war: Evidence and analysis. Washington: The World Bank, p. 35-58, 2005.

[17] A.Setyadi, Pilkada Aceh 2017: hasil akhir pleno KIP Aceh: pasangan Irwandi-Nova unggul. Retrieved from https://news.detik.com/berita/d-3432015/hasil-akhir-pleno-kipaceh-pasangan-irwandi-nova-unggul, on August 21, 2017.

[18] P. Schwartz, The art of the long view. In Global Business Network. Retrieved from file:///C:/Users/NMVSTHC/Downloads/Art\%20of\%20the\%20Long\%20View\%20Excer pt.pdf, on August 21, 2017, 1991. 